\title{
Collegiality and its Role in Teacher Development: perspectives from veteran and novice teachers
}

\author{
DEBORAH LEE HARRIS \\ Florida Atlantic University, USA \\ HELENE M. ANTHONY \\ College of New Jersey, USA
}

\begin{abstract}
The nature of collegiality and its role in teachers' professional development is explored by comparing two data sets: one analysing the interviews with a veteran social studies teacher reflecting on her 30-year teaching career, and the other analysing the conversations of six beginning teachers as they participated in a shared inquiry group. Two different types of relationships with colleagues are described, one that provides a supportive working environment and one that results in significant professional growth. Implications for in-service professional development are discussed.
\end{abstract}

\begin{abstract}
Teaching is not something one learns to do, once and for all, and then practices, problem-free, for a lifetime ... Teaching depends on growth and development, and it is practiced in dynamic situations that are never twice the same. Wonderful teachers, young and old, will tell of fascinating insights, new understandings, unique encounters with youngsters, the intellectual puzzle and the ethical dilemmas that provide a daily challenge. Teachers, above all, must stay alive to this. (Ayers, 1993, pp. 127-128)
\end{abstract}

\section{Introduction}

Helping teachers 'stay alive' to the challenge of learning from their own practice has long been a goal of teacher educators, administrators and district staff development personnel. For many years, attempts to promote ongoing teacher learning involved 'training' teachers to use a particular method or set of techniques, often in one-shot workshops that were notoriously unpopular with teachers and generally ineffective in promoting substantive change in 
their practices. Such efforts, described by Lieberman (1995) as 'technical tinkering,' are likely to fail, in part because they 'infantalize teachers and push them into patterns of defensiveness and conservatism' (Lieberman \& Miller, 1999 , p. 5). The current professional development literature advocates a very different approach. Working from the perspective that teachers deserve to be treated as professionals, as active inquirers who are able to direct and take ownership of their own learning (Clark, 1992; Darling-Hammond \& McLaughlin, 1995; Grossman, 1992), educators now recommend that teacher development efforts be focused, inquiry-orientated and sustained over a long period of time (Ashburn, 1995). Teachers are encouraged to work together, to collaboratively solve problems of practice (in much the same way that constructivist teaching engages students in the classroom). Whether in teacher networks or study groups, grade level teams or professional development schools, there is a focus on creating a community of learners in which there is 'a shift from teaching in isolation and one-on-one mentoring to school-wide collaboration and conversation' (Middleton, 2000, p. 52).

A central theme underlying many of the current attempts to promote teacher development has been the notion that collaboration and collegiality contributes to teacher growth. Despite the fact that the term 'collegiality' remains somewhat problematic, as it is ill-defined, over-used, and open to multiple interpretations (Darling-Hammond \& McLaughlin, 1995; Hargreaves, 1993), it has come to be viewed as a critical feature of effective development efforts. Indeed, as Little (1990b) has noted, collegiality advocates 'have imbued it with a sense of virtue - the expectation that any interaction [emphasis added] that breaks the isolation of teachers will contribute in some fashion to the knowledge, skill, judgment, or commitment that individuals bring to their work, and will enhance the collective capacity of groups or institutions' (p. 509). Although the potentially pivotal role of collegiality in teacher development has been widely discussed in the literature, many questions remain unanswered: What is it about collegiality that makes it so powerful? What are the conditions under which true collegiality (as opposed to the 'contrived' collegiality described by Hargreaves (1993) can flourish? How are collaboration and collegiality related? Do teachers (i.e. beginners and veterans) experience collegiality differently?

In this article, we present examples of two sets of teachers who were engaged in the kind of learning now being promoted by those in the teacher development field. In both cases, collegiality played a significant role in that learning. Interestingly enough, the teachers involved were two veteran and six novices, groups who are frequent targets of staff development efforts. In both cases, though, the teachers themselves sought out the development opportunities. In both instances, the experience was so intrinsically rewarding that they willingly gave up many weekend days and evenings to participate. These cases defy the folk wisdom that old and new teachers are less capable of professional development, either because they are 'too inexperienced and lacking in pedagogical knowledge', or because they are 'burned out and too set 
in their ways.' We believe that a close examination of cases such as these can contribute to educators' understanding of what is needed to promote the kind of collegiality that teachers at different career stages view as critical to their ongoing learning. We agree with William Ayers that 'teachers can be the richest and most useful source of knowledge about teaching; those who hope to understand teaching must turn at some point to teachers themselves' (in Schubert \& Ayers, 1992, p. v).

The data discussed here was collected over the course of a school year and includes transcripts of in-depth interviews and monthly group conversations, observational field notes, and documents such as journal entries and lesson notes. One researcher (HA) observed and interviewed a social studies teacher, Karen Anderson, during her thirtieth year of teaching; she felt that her approach to instruction had undergone significant changes over her career. The other researcher $(\mathrm{DH})$ explored the role of conversation in the formation of teachers' professional identities by analysing the discussions of a group of novices as they met monthly in a shared inquiry group. We now present our analysis of the data describing the role of collegiality in Karen's teaching career, and follow that with a comparison to the novice teachers' experiences.

\section{Finding a Supportive Environment}

Karen began teaching full-time in 1965 after completing an undergraduate degree in pre-law and then a teacher certification programme in secondary social studies. She reported that she felt ill-prepared for her entrance to teaching. In her first position, one of her assignments was teaching geography, a content area she had not even studied in college, to the 'bottom track' of students in a basement classroom. After what she described as merely 'surviving' her first year of teaching, Karen decided to either transfer to another school or leave the profession. She received her transfer-a careershaping event-and remains at that school today. The most significant difference Karen identified between the two school settings was the school climate-specifically, she described differences in her interactions with fellow teachers. These interactions varied in terms of the support offered, the view of learners espoused and status held relative to other faculty.

Emotional Support. It was evident from Karen's comments about her first year teaching experience that she did not feel emotionally supported in that setting. Among other things, her principal continually challenged her instructional decisions and she was assigned difficult students to teach, yet was given outdated and inadequate materials to use. While a major obstacle to Karen's professional growth that year was her principal, her comments indicated that fellow faculty were also a problem, as they were generally unsympathetic and unapproachable. Karen did meet with two other beginning teachers with whom she could commiserate, but she clearly lacked the support of 
encouraging colleagues, particularly among more experienced faculty. In contrast, at the second school, she found a group of people with whom she could talk without the fear of evaluation:

There was a group of us who watched and reflected and talked and asked questions, and I think kind of goaded each other. But it was a very supportive environment because I was never ridiculed for asking questions. It was the sort of environment where you never worried about admitting that everything wasn't hunky-dory in your class.

Karen provided examples of some of the qualities that made her school's environment a collegial one, i.e. that experienced faculty assisted her with learning various routines of the building, and encouraged her on a 'bad day.' She painted a picture of being cared for, both personally and professionally. This kind of support had been sadly missing the year before.

Views about Learners. The way that administrators and fellow faculty talked about students was another clear difference between Karen's two teaching experiences. In her first position, Karen and the other new teachers in the building were instructing students who had been placed in the lowest ability track. The derogatory language used by the more experienced teachers to describe the children she taught bothered her tremendously and prevented Karen from seeing these people as good colleagues:

Most of the kids were probably learning disabled, maybe dyslexic. They couldn't read. They were not dumb kids. There was nothing wrong with their intellect but they couldn't read and because of that they were classified as non-learners. The term that was most commonly used among the staff was 'doorknobs.'

In her second teaching position, she described much friendlier conversations with fellow teachers, mostly in the 'smoke room,' in which 'there were some jokes made about some kids, but there was never the mean-spiritedness that you hear about in teachers' lounges.' It became apparent that in her new school, the faculty conversed about their students and their families with an intent to solve problems. Shared information focused on relevant facts and descriptions needed to understand and address the situation, rather than statements that could be characterised as gossip or malicious talk.

Relative Status. Unlike her experiences that first year, where Karen's interactions with colleagues were limited almost exclusively to beginning teachers like herself, in her second position she was the only new teacher and, rather than feeling isolated, she felt welcomed. In the 'smoke room' she interacted daily with English, math and foreign language teachers with various years of experience:

The average age of the staff was probably mid-40's and I was about 25. They

kidded me about my short skirts ... but it was a supportive environment ... The 
smoke room was probably one of the most intellectually stimulating places you could be.

Despite Karen's lack of experience relative to her fellow teachers, she felt she was accepted as an equal participant in her colleagues' discussions.

\section{Building a Collegial Relationship}

While Karen clearly enjoyed being a faculty member in her second school, it was also true that over the years she felt a growing sense of dissatisfaction with her own practice. After the birth of her children, Karen says she saw teaching differently:
In the fall when I went back, I walked in and for the first time every single, individual child in that classroom was somebody's baby. I'd always tended to see them as groups, and that's all I saw. I started to see and to become much more aware of individual differences and the individual child.

As time passed, she continued to wonder why her students rarely showed the intense interest in learning that her two young daughters did. This became a source of significant concern to her and she again considered leaving the profession:
Despite these things that were essentially positive, I was very close to leaving ... I was reading everything in the professional literature on burnout ... I think there was such a wide gap between my picture in my head about what learning and teaching ought to be about and what the reality was ... I knew what I was doing wasn't working. It was like I was spinning my wheels and I don't know any of us that will stick with something that's fruitless for too long.

Even though Karen felt she was working in a supportive environment, she was having difficulty making the progress she desired in her professional development. This appears to be partly because Karen's interactions with good colleagues did not involve substantive conversations about what they did each day and why. When discussing a geography teacher whom she respected a great deal, her final comments highlight what was lacking in this supportive environment:

She was a very strong social studies colleague but she was in geography and I was in history and they are very different disciplines. She was a very professional teacher who certainly influenced me but we didn't ever work together... There was nobody I could brainstorm with in terms of what I did in the classroom.

This was all about to change as Karen, in her eigthteenth year of teaching, began talking with a new teacher in the building, someone who had taken time off from teaching to raise her children, and was also assigned 8th grade US History. By the end of the year, Karen and her new colleague, Laurie, had decided to work together over the summer to read some professional literature. Thus, began what appears to be a truly collegial relationship that 
resulted in significant professional growth for both teachers, as evidenced by the substantive changes in Karen's classroom practice. She started using cooperative learning, and emphasised the teaching of thinking skills through history instead of merely learning historical facts. In her words, 'I used some of the exact same materials that I'd developed years ago, but in different ways and for a different purpose.' Consistent with the literature on qualities that promote teacher learning and development, Karen and Laurie's relationship was characterised by having a shared focus, engaging in self-directed inquiry and reflection, and providing each other with instructional support. Like the team relationships described by Nias (1989), it grew slowly, but quite strongly over time, as they found the results 'reaffirming for themselves and fruitful for their pupils' (p. 161).

Shared Focus. Several researchers (e.g. Lieberman, 1995; Pennell \& Firestone, 1996; Vukelich \& Wrenn, 1999), contend that true collegial relationships are those in which participants are united by a 'common purpose and shared identity.' Clearly, Karen and her colleague had a shared focus by virtue of the fact that they were teaching the same course at the same grade level. They also shared a commitment to diverge from traditional social studies teaching, and to find ways to promote student engagement and thinking around the topics in their course, even though they could not predict what that might involve:

The first year we worked together is the year we got all the thinking skills issues of Educational Leadership. So it was sort of a fateful confluence that these things kind of came together because the next summer we really set out to read all of those. We were going to do something different.

Self-directed Inquiry. Another facet of collegial relationships that emerged from discussions with Karen was the self-directed nature of their activity. They voluntarily pursued self-identified problems and questions of practice:

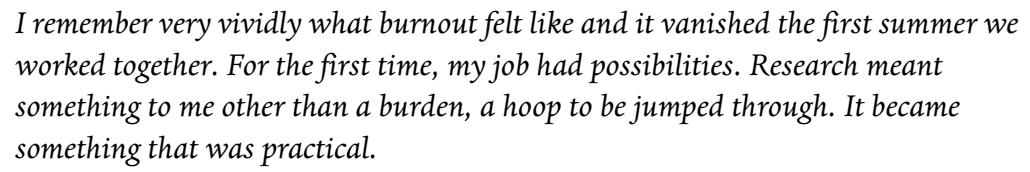

Karen and Laurie established a pattern of working together that included deciding on what to read, meeting to discuss it, working individually to develop teaching ideas, sharing notes, and so forth. In describing this process, Karen made a clear distinction between her work with Laurie and her previous discussions with good colleagues:

Laurie and I sort of fell into a problem solving mode and we found solutions that worked. Before that, the environment was very supportive but nobody had any real solutions.

Reflection. For about 5 years, Karen and Laurie's collaboration involved meeting together during part of their summer vacation, and most Sunday 
afternoons during the school year. During these sessions, they reflected on how specific activities had fared in their different classes, and they planned for future lessons and units. Particularly in the beginning of their working relationship, Karen and Laurie wrestled with issues such as how to design activities that would make students think about content, how best to use cooperative learning strategies, and how to assess students' preparation for and participation in learning activities. All of these issues and more were discussed in depth when they met. In describing what would take place in their meetings, Karen shared this insight:

It's when I would reflect back and talk to Laurie that I would start to recognize things, like, 'Yes, I have seen a pattern' ... patterns in terms of the way in which students interpreted things. We would pick up on misunderstandings that were patterns across our classes.

Instructional Support. While good colleagues will provide each other with a general degree of emotional support, it was clear that Karen and Laurie provided each other with support at a very different level. All growth, even desired growth, involves some degree of fear and risk-taking. Karen and Laurie's collegial relationship was instrumental in providing a safety net that allowed them to try things they had never tried before and to keep failure in perspective:

We constantly reminded one another to focus on the positives. It's so easy to look only at something that didn't work, and to lose sight of the big picture ... One of the things we offered each other support on when we started using cooperative groups, was remembering that just because it didn't work with a couple of groups but it did work with the other thirty [groups], maybe we better not write this off.

After Laurie transferred to another building and began teaching a different grade level from Karen, their relationship changed significantly. Although they kept in contact and continued to discuss aspects of their teaching, they no longer met to co-plan and collaborate on daily assignments. Karen referred to her last few years of teaching as a period of 'coasting' in which she relied on using most of the materials and activities she had developed with Laurie. During a unit that HA observed, Karen reported that she was 'terrified' to try out a new computer database assignment because of her own lack of skill in manipulating databases. This one change in a classroom assignment was difficult for Karen to undertake. Such a change would likely have been much less stressful if Laurie had still been present in the building, trying out the same assignment with her own classes.

Being in a school with a supportive environment and 'good colleagues' was certainly an important condition in fostering Karen's commitment to her own ongoing learning. In fact, it kept her from leaving the profession after her first year. However, it was not a sufficient condition for ensuring substantive change in practice, as Karen considered leaving again when she felt frustrated by her teaching. It was only the development of a more intensive and focused relationship with Laurie that kept Karen in teaching and interested in teaching 
well. This collegial relationship, in short, provided the avenue for Karen's professional development. Friend \& Bursack (2000) would describe this kind of collegiality as collaborative in nature, as it included mutual trust and respect, shared decision making, shared accountability and shared goals.

Karen's experiences as a beginning teacher were 30 years ago, during an age in the profession marked by its emphasis on individualism and isolationism (Hargreaves \& Fullan, 2000). Given the more recent push for cooperation and collaboration within classrooms, we wondered if the beginning teachers in the 1990s had found it easier than Karen had to find a supportive environment with good colleagues. We turn now to our analysis of the data collected in DH's study of first and second year teachers' development of a professional identity.

\section{Lack of a Supportive Environment}

The six novices in the study were members of a teacher inquiry group that met for 4-5 hours monthly over a 12-month period. All the novices had graduated from an alternative programme grounded in the work of John Dewey and Joseph Schwab. The goal of the 'Learning Community' programme was to 'prepare teachers to teach school subjects effectively, while also focusing on the development of personal and social responsibility among students' (Florio, 1981). The programme was organised around common themes, and articulated in a set of 'propensities' or internal dispositions toward particular kinds of thought and action. Teacher candidates moved through a two-year sequence of carefully orchestrated, coherent set of course and field work experiences in small (20-25 student) cohort groups. A cluster of interdisciplinary faculty who shared common understandings of the programme's conceptual framework and goals worked closely with each cohort group in multiple contexts over the 2 -year period. The faculty explicitly sought to foster a sense of community and collegiality through the development of shared values among members and engagement in collaborative activities, both academic and non-academic in nature. After graduation, the six teachers in the inquiry group (referred to here as the LC Sharing Circle) had obtained positions at different grade levels in six different schools in two states. In all but one case, each participant was the only new hire in the school and was younger than fellow teachers by at least 12 years (and, in one case, close to 30 years).

Unlike Karen, whose curricular decisions had been scrutinised and criticised by her principal, the beginning teachers in the LC Sharing Circle had little to say about their principals. They did, however, have quite a bit to say related to their day-to-day interactions with fellow teachers. Apart from the references to the students they taught, other teachers were their most frequent topic of conversation, raised in fact, 49 times over the year. Disturbingly, however, the beginning teachers found few good colleagues at their new schools who made them feel supported or accepted as equal associates. 
Emotional Support. There were many different situations in which the novices felt that their school peers were openly discouraging and quick to unfairly prejudge their efforts. They described feeling as if they were being watched, almost spied upon, when they were regularly questioned about which chapter in the mathematics text they were teaching. Ironically, they were made to feel incompetent, whether they were 'behind' the other teachers or 'ahead' of them. Amy explained: 'Maybe they're thinking I didn't cover it enough or they didn't really learn it.' They were teased about writing out detailed lesson plans, warned that by using a holistic approach to literacy instruction their students wouldn't learn important skills and sometimes overtly discouraged from taking specific actions. Several of the LC teachers, for example, described their attempts to implement a writer's workshop in their classrooms, only to be told by their school peers that 'We don't do that here.' Although Amy claimed to feel relatively confident that she was making appropriate instructional decisions, she did not feel able to defend her actions to the other teachers in her school. In one instance, she describes listening to several teachers as they informed her that a skills-based approach was superior to the more holistic approach to literacy teaching that she had adopted.

Amy: ... But I find that I'm kind of chicken when teachers say those kinds of things, I always just say, 'Well, there's pluses and minuses to both systems, right?' I always cop out like that, I'm not quite to the point where I feel comfortable, just saying, 'Well, I totally disagree with you' or something like that.

Claire: It's hard, too, because that's the way we were brought up, and they say, 'See, you can read, you can write.'

Deb: Right, that's an argument they can always use.

Claire: Yup.

Deb: And you might not be able to change their mind by just saying 'I don't agree with you.'

Amy: And you might just make an enemy, there too.

Deb: Mmmmm.

Amy: I usually just find some middle of the road thing, you know, 'Oh, there's good and bad, there's pluses and minuses.' I just kind of try to keep the peace, with what I'm doing in my room anyway...

Each of the LC teachers had only one or two school peers from whom they found encouragement and support, teachers that could fit the description of being 'a good colleague.' Much of the novices' energy went into trying to gain their peers' acceptance and trying to do what Val described as 'making good 
rapport.' First year teacher Amy and second year teacher Claire compare experiences:

Amy: [There's] one 2nd grade teacher just makes me so - she makes me feel so good because she comes down, she asks me questions, she asks my advice, and she is truly interested in what I have to say. And I find myself asking her things before I'll go and ask someone else, 'cause she really listens to me, where other people are kind of like, 'Oh that's all fine and dandy, but you've got the good kids anyway.' That's their excuse for anything that I'm doing right now. We just traced our bodies and then we put all of our organs in it and our bones, and you know, it was neat, because it was all actual kid size - they each traced their own body with their partner and everything - and somebody came by and saw it, and then, they were talking about it, and I heard them out in the hall, and she was saying: 'Oh well, she's got all the good kids anyway.' That's their excuse for everything. But, we'll see what they say next year ... 'Cause I keep telling the other 3rd grade teachers that I'll take my share next year.

Claire: That's exactly what they said to me last year, 'Just wait till next year,' they said. 'These 2nd graders are going to com ...' and I - they always said I had all the - that I had the good class. And that's the only reason why we got to read and write all these books and do posters and plays and things like that.

Views about Learners. Of all their interactions with school peers, the aspect they found most discouraging related to the other teachers' lack of concerned talk about students and their families. The novices did not want to eat or even sit in the staff rooms, because the teachers were, in Amy's words, 'so goddarned negative.' They were uncomfortable with the tone of the talk, its emphasis on 'trashing' or belittling students, rather than on solving problems or helping students - and yet were afraid to stay away from the staff room for fear of being seen as 'snobby.' Just as it had bothered Karen all those years ago to hear her students being referred to as 'doorknobs' and to hear talk that exacerbated the students' problems without solving them, so too did teachers' negative talk bother the LC novices.

Lauren: I eat lunch with some teachers who are so negative! And its like, God, how can you be a teacher?

Val: [Mmmhmm!]

Amy: [I know!]

Lauren: I mean they're so down on the kids, they're so down on the [schools]-

Val: [the system -

Lauren: Everything! They're so negative! It's like, 'Why can't you be a little bit more - like, hopeful?'

Val: Yeah, [that's - 
Lauren: [And Duane] and I just sit there. And we're just sitting there looking at each other going 'Oh boy ...'

Relative Status. The differences in age, number of years in the profession and experience caused the novices to feel lower in status, and thus power. One novice commented that they were definitely 'the new kids on the block,' and all seemed reconciled (albeit reluctantly) to having to 'pay their dues' by taking the most challenging students, working in the least desirable classrooms, having the oldest textbooks or fewest manipulatives or other resources. While these beginning teachers felt (and rightfully so), that they 'could do the workshop on cooperative learning' that their schools had been mandated to attend, they were always put in a position of receivers, rather than disseminators, of information. There seemed to be no recognition amongst their colleagues that even though beginning teachers do not have the same knowledge as veterans - since there is much that is learned through the practice of teaching - they do bring expertise that may be equally valuable to the enterprise of teaching, e.g. new insights into student diversity, new ideas about management, knowledge of new instructional techniques, and so forth (Hargreaves \& Fullan, 2000).

\section{Building Collegial Relationships in an Inquiry Group}

While it is fairly evident that these beginning teachers would find it difficult to develop true collegial relationships in their schools, since they did not report even having good colleagues to offer minimal emotional support, the LC Sharing Circle appeared to have many of the qualities of Karen and Laurie's collaborative relationship described earlier in this article. The relationships developed within the Sharing Circle made them feel safe and valued. In an interview at the end of the study, Val remarked that the Sharing Circle was a haven, a place where 'You feel like you can come and spill your guts and not have anyone second guess you or critique you or think you're a bad teacher.' The same four characteristics, having a shared focus, engaging in self-directed inquiry, creating opportunities for reflection, and gaining instructional support were all present in the Sharing Circle.

Shared Focus. Although not teaching in the same school, their common teacher education programme united the beginning teachers in a significant way. Val described the group as a kind of lifeline that linked them to the progressive principles they valued. Amy Roberts agreed, commenting that:

It's so nice to be able to get back with people who thought like you thought, believed like you believe and just almost like touch ground with your beliefs, like 'Yes, what I'm doing is okay.' Even though everyone else in the school might be looking at me like I'm strange, what I'm doing is okay and it is right, and I can keep trying it. 
Having a common vision of the kind of classroom community they were trying to create was important to them, especially since the democratic ideals they were trying to foster stood in stark contrast to the practices they saw other teachers implementing. Claire explained in an interview at the end of the school year that the other people in the group had a similar mindset and thus 'they knew you were trying to get to a certain kind of understanding with the kids and their parents. They just knew, they've been there.'

Self-directed Inquiry. That the novices wanted to belong to the group was clear, as evidenced by the fact that they drove from points across the state of Michigan and Ohio, even in bad winter weather to meet. Although DH served as a facilitator for the group, the Circle members directed the course of the meetings, initiated topics, brought problems or dilemmas to discuss and materials to share. The members themselves determined how long to focus on a topic, and when to move on. They often brought artifacts (i.e., photographs of their students or work samples) to pass around, and many of the topics initiated became themes that wove through subsequent meetings. In their stories about their efforts to work with 'special needs' students, for example, the novices revealed their willingness to wrestle with complicated problems of practice such as the teacher's role in ensuring equity in the classroom.

Reflection and Instructional Support. The Sharing Circle was a setting in which the novices felt free to share their triumphs and disappointments, their questions and concerns about students, schools, curriculum, teaching, and learning. They gave and sought instructional advice for specific problems (e.g. how to make time to hear all the literature group discussions, or how to give feedback on students' writing without taking home 'bags and bags' of papers), as well as on more general problems relating to grouping students and assessing their learning. Having a place to talk in this way reduced the isolation that novices typically feel. In one interview, Julie remarked that:

The other teachers try to scare you by telling you these horrible tales, which you
don't listen to. It's difficult coming out of the kind of community where you were
used to being able to talk about the things you were planning, how they were
going, sharing materials - to a situation where you're on your own. You don't
have the materials, you don't have the money to purchase everything that you
need, and you're not with a whole staff of people you can bounce your ideas off of.

The Sharing Circle also provided an occasion for them to reflect on their evolving practice. This was important, for as Richert (1992) reminds us, 'in addition to norms of the profession, the demands on teachers' time preclude much reciprocal conversation among colleagues; teachers are too busy to listen to themselves let alone listen to one another' (p. 193). In most schools, while there are multiple opportunities for teachers to interact with one another, there are few occasions - either during or after the school day - for teachers to actually talk substantively about teaching and learning (Feiman- 
Nemser \& Floden, 1986). Whether new or experienced, teachers juggle enormous demands and responsibilities - they must attend meetings and workshops, write reports, evaluate and design curriculum, be on lunch duty, supervise the production of plays and newspapers, and more-in addition to their primary job of teaching students in their classrooms something worthwhile (Wigginton, 1986).

The Sharing Circle provided its members with time and encouragement to share stories of teaching, The telling of stories is important, as Helen Featherstone (1992) explains, because:

In telling stories we create a space outside of the relentless stream of experience and demands. We represent both our understandings and the contexts which have created them, streamlining a series of lived events, selecting salient details to highlight. (p. 3)

Telling a story to someone else puts us in touch with what we know and are coming to know, while at the same time, lets us step back from that knowing in order to reflect upon it, to 'look over our own shoulder,' so to speak. However, telling stories does more than simply help us understand and reflect upon our lives. The personal narratives we tell ourselves and others actually come to structure how we perceive information and experiences, and ultimately determine the way we organise and make sense of our world. In addition, reflecting on their instructional decisions first (in the group setting) gave the novices courage to share their decisions with others outside the group. Claire explained it this way: 'Once you talk about it with a group like this, its easier to go and talk about it with a principal or parent or someone else.'

\section{Collegiality and Professional Development}

The importance of teachers' continued professional development cannot be underestimated (Lieberman \& Miller, 1999; Hargreaves \& Fullan, 2000), especially during this era of increasing demands on teachers' expertise and higher expectations for their accomplishments. Demands for more rigorous standards and school restructuring, as well as calls for more inclusionary practices to accommodate an increasingly diverse student population are just a few of the reforms that have upped the ante for teachers. With regard to the standards movement, Wilson \& Ball (1996) conclude, 'professional development is central to any change effort in schooling, and there is a growing awareness of this point on the part of policy makers, administrators, parents and teachers alike' (p. 134). All these demands, however, can be exhausting and demoralizing for teachers, as Hargreaves \& Fullan (1998) point out: 'Too much educational reform and restructuring is destroying teachers' confidence, draining their energy, eating up their time and taking away their hope' (p. 3). How then can we promote professional development in ways that engender hope and success? Given the consensus that traditionally delivered 
workshops do not promote teacher learning and do not result in significant change in practice, many schools are attempting to create opportunities for teachers to become more 'collegial' (e.g. through mentoring programmes, interdisciplinary teams and teacher networks).

What insights can we offer based on the data described here? First of all, our analysis of the data revealed two important, but distinct types of collegiality - collegial interactions that helped produce an emotionally supportive work environment, and collegial interactions that truly engendered significant professional development. Our synthesis of comments made by Karen and the beginning teachers indicate that a supportive, collegial environment is one in which colleagues keep open the lines of communication, and listen to both the concerns and ideas of others. Good colleagues respect their students and discuss their needs, not their inability to learn. Supportive colleagues don't make inquiries for the purpose of evaluating another's work, rather they converse with peers out of genuine interest in what they're doing. They take pride in each other's accomplishments and recognise the efforts of others, not seeing themselves as in competition with one another. Knowing that beginning teachers continue to leave the profession in high numbers - indeed, nearly $50 \%$ leave within the first 6 years (Huling-Austin, 1985) - we should be particularly conscientious about seeking ways to promote more supportive environments in which teachers can interact with students and each other.

However, as important as a supportive environment was to Karen remaining in teaching, and as much as the novice teachers seemed wistful about not having more encouraging colleagues, a supportive environment alone is not a sufficient condition for teacher development (Day, 1999). While positive, there is an informal, perhaps superficial quality to the interactions. For our set of teachers, it was only the more personal, collaborative, and intensive relationships with colleagues - what Little (1990b) might call the 'strong ties' - that showed potential to foster ongoing professional development.

For colleagues to truly 'collaborate' and take ownership of the process of inquiry together, they need to have some shared values, goals and/or a common vision of teaching. They must have a relationship that is characterised by trust, care and mutual respect. They have to be comfortable sharing self-doubts without feeling like a failure, as well as celebrating successes without feeling arrogant. In a true collegial relationship, peers must be willing to give and receive both constructive feedback and reinforcement (McLaughlin, 1994). The time required to do these things means that there must be a serious commitment by all participants to the issue at hand. An additional challenge to those seeking to promote true collegiality, of course, is that while the formation of such relationships cannot be left to fate or happenstance, neither can they be coerced, mandated or prescribed. Educators have proposed a number of ways to try to encourage the development of collegial relationships, three of which we describe briefly below. Each offers 
some promise, and yet our work with Karen and Genie, and the LC novices tell us that each has limitations, as well.

\section{Mentoring}

Everyone recognises the need to provide assistance to beginning teachers, specifically during their first years in the classroom. While mentoring programmes have become much more prevalent in the past 10 years (Little, 1990a), only one of the beginning teachers in the LC Circle was in a school that had such a programme. It would seem that these programmes should be able to provide beginning teachers with an adequate level of emotional support and with a structure for discussing students in a positive way. However, while there is increasing research on mentoring programmes and recognition that the 'mentor/protégé relationship provides a vehicle for reflection and dialogue' (Dever \& Hobbs, 1998), current mentoring models appear to perpetuate the assigning of unequal status to teachers (Little, 1990a; Meyer $\&$ Achinstein, 1998). Cole (1991) has also pointed to the limitations that 'assigned partnerships' can have, both in terms of their usefulness and their long-term viability. It is still unclear in what ways these programmes would need to be organised to facilitate collegial relationships that lead to professional development, for the mentor as well as the mentee.

\section{Interdisciplinary Teams}

Many schools, particularly at the middle school level, have established interdisciplinary teams of four or five teachers who share a group of students. The greatest concern with this arrangement seems to be that teachers generally have no say in the formation of teams and, therefore, it can be an instance of 'contrived collegiality' (Hargreaves, 1992). Both Karen and Laurie were involved in interdisciplinary teams the year HA interviewed them. While Laurie's team was doing a significant amount of co-planning and thematic teaching, Karen's team limited their discussions to observations and methods with individual students. The co-planning task of Laurie's team appeared to produce a more salient shared goal that facilitated self-directed inquiry, reflection and instructional support. It is unclear at this point what factors contribute to an interdisciplinary team's success in being a site for professional development. One critical factor, though, appears to be time. Both Karen and Laurie said that time was the greatest obstacle to professional development, and interdisciplinary teams rarely have more than an hour a day, sometimes an hour a week, for their planning. This is a far cry from the 3-4 hours that Karen and Laurie spent each weekend over many years engaged in inquiry and reflection about their teaching. Another factor may be inexperience with coplanning and shared inquiry. Few teachers learn these skills while candidates in teacher education programmes (Cook \& Friend, 1991) and so may not 
automatically be successful with this, even if they were provided with adequate time during the school week.

\section{Teacher Networks}

Groups of teachers who converse outside of school, either electronically or in face-to-face 'study' group meetings or networks, show great potential as sites for focused, ongoing, and self-directed inquiry by teachers (Lieberman \& McLaughlin, 1992; Pennell \& Firestone, 1998). A long-established form of inservice education in Japan (Shimahara, 1998), these voluntary groups are now increasingly being viewed in North America, Israel and the United Kingdom as a legitimate forum to promote teacher development. Teachers in these informal networks, which may or may not be sponsored by a university or school district, come together - united by a common interest in a particular subject matter, issue or type of teaching - to interact as both teachers and learners. During meetings, teachers converse, share stories, plan instruction or even share results of their own action research projects (Campbell, 1988; Hunsaker \& Johnston, 1992; Wilson et al, 1993). For teachers like Karen, who almost left the profession twice, once because she was unsupported and once because she felt she was not developing satisfactorily as a teacher, membership in a teacher network would have been valuable. It was only by chance, what she called a 'fateful confluence,' that she was able to collaborate with Laurie on topics of interest that were current in the professional literature. Establishing teacher networks and developing a culture of teacher inquiry, holds some promise for reducing the randomness or serendipitous nature of professional development (Sachs, 1997). One unresolved problem with networks, however, is their potential for creating an 'us-versus-them' mentality between those in and outside of the network. We wonder, for example, whether the LC Sharing Circle contributed in any way to the novices' feelings of being isolated and disconnected from the other teachers in their schools. Another unresolved issue relating to networks is that their power lies in the fact that members' participation is voluntary. If you mandate that teachers join a network or try to engineer their participation, do you then lose this powerful element?

\section{Conclusion}

In summary, providing teachers opportunities for continued development as they practice their profession is crucial for meaningful change in any educational system. As Barth (1990) notes, 'probably nothing within a school has more impact on students in terms of skills development, self-confidence, or classroom behavior than the personal and professional growth of their teachers' (p. 49). In order for teachers to view themselves as lifelong learners, as practitioners who actively seek out the kinds of professional activities which will promote their own growth in teaching, schools will need to respond by 
orchestrating ways for all teachers to feel supported, and providing genuine opportunities for teachers to collaborate and study issues of importance to them. When this does happen, Nias observes, teachers are indeed able to '... find new levels of self-extension and of fulfillment in their work, moving beyond pleasure and satisfaction to an all-absorbing delight, in each other and in the task' (1989, p. 155). Listening to teachers such as Karen and Laurie, as well as the LC Sharing Circle novices offers some direction for how schools might proceed.

\section{Correspondence}

Deborah Lee Harris, Department of Teacher Education, Florida Atlantic University, 5353 Parkside Drive, Jupiter, FL 33458, USA (dlharris@fau.edu).

\section{References}

Ashburn, E. (1995) Teacher-led Inquiry: a compelling direction for the education of teachers, Action in Teacher Education, 17(3), pp. 79-86.

Ayers, W. (1993) To Teach: the journey of a teacher. New York: Teachers College Press.

Barth, R.S. (1990) Improving Schools from Within. San Francisco: Jossey-Bass.

Campbell, D. (1988) Collaboration and Contradiction in a Research and Staff- Development Project, Teachers College Record, 90, pp. 99-121.

Clark, C.M. (1992) Teachers as Designers in Self-directed Professional Development, in A. Hargreaves \& M. Fullan (Eds) Understanding Teacher Development. New York: Teachers College Press.

Cole, A. (1991) Relationships in the Workplace: doing what comes naturally? Teaching and Teacher Education, 7(5/6), pp. 415-426.

Cook, L. \& Friend, M. (1991) Principles for the Practice of Collaboration in Schools, Preventing School Failure, 35(4), pp. 6-9.

Darling-Hammond, L. \& McLaughlin, M. (1995) Policies that Support Professional Development in an Era of Reform, Phi Delta Kappan, 76, pp. 597-604.

Dever, M.T. \& Hobbs, D.E. (1998) The Evolution of a Teacher: a 2-year case study, Teacher Development, 2, pp. 385-404.

Featherstone, H. (1992) Learning from the First Years of Classroom Teaching: the journey in, the journey out, NCRTL Special Report. East Lansing: Michigan State University, National Center for Research on Teacher Learning.

Feiman-Nemser, S. \& Floden, R.E. (1986) The Cultures of Teaching, in M.C. Wittrock (Ed.) Handbook of Research on Teaching. New York: Macmillan.

Florio, S. (1981) The Learning Community: teaching for personal and social responsibility, A program emphasis description prepared for the core group of the Learning Community, College of Education, Michigan State University.

Friend, M. \& Bursack, W. (1996) Including Students with Special Needs: a practical guide for classroom teachers. Old Tappan, NJ: Prentice Hall. 
Grossman, P. (1992) Teaching to Learn, in A. Lieberman (Ed.) The Changing Contexts of Teaching: ninety-first yearbook of the National Society for the Study of Education. Chicago: University of Chicago Press.

Hargreaves, A. (1992) Cultures of Teaching: a focus for change, in A. Hargreaves \& M. Fullan (Eds) Understanding Teacher Development. New York: Teachers College Press.

Hargreaves, A. (1993) Individualism and Individuality: reinterpreting teacher culture, in J.W. Little and M. McLaughlin (Eds) Teachers' Work: individuals, colleagues, and contexts. New York: Teachers College Press.

Hargreaves, A. \& Fullan, M. (1998) What's Worth Fighting for out There. New York: Teachers College Press.

Hargreaves, A. \& Fullan, M. (2000) Mentoring in the New Millennium, Theory Into Practice, 39, pp. $50-56$.

Huling-Austin, L. (1985) Teacher Induction Programs: what is and isn't reasonable to expect, Research and Development Center for Teacher Education Review, No. 3. Austin: University of Texas

Hunsaker, L. \& Johnston, M. (1992) Teacher under Construction: a collaborative case study of teacher change, American Education Research Journal, 29, pp. 350-372.

Lieberman, A. (1995) Practices that Support Teacher Development: transforming conceptions of professional learning, Phi Delta Kappan, 76, pp. 591-596.

Lieberman, A. \& McLaughlin, M. (1992) Networks for Educational Change: powerful and problematic, Phi Delta Kappan, 73, pp. 673-677.

Lieberman, A. \& Miller, L. (1999) Teachers: transforming their world and their work. New York: Teachers College Press.

Little, J.W. (1990a) The Mentor Phenomenon and the Social Organization of Teaching, in C. Cazden (Ed.) Review of Research in Education. Washington DC: American Educational Research Association.

Little, J. W. (1990b) The Persistence of Privacy: autonomy and initiative in teachers' professional relations, Teachers College Record, 91, pp. 509-536.

Little, J.W. \& McLaughlin, M. (1993) Introduction: perspectives on cultures and contexts in teaching, in J.W. Little \& M. McLaughlin (Eds) Teachers' Work: individuals, colleagues, and contexts. New York: Teachers College Press.

McLaughlin, M. (1994) Strategic Sites for Teachers' Professional Development, in P. Grimmett \& J. Neufeld (Eds) Teacher Development and the Struggle for Authenticity: professional growth and restructuring in the context of change. New York: Teachers College Press.

Merseth, K. (1992) First Aid for First-year Teachers, Phi Delta Kappan, 73, pp. 678-683.

Meyer, T. \& Achinstein, B. (1998) Collaborative Inquiry Among Novice Teachers as Professional Development: sustaining habits of heart and mind. ERIC Document Reproduction Service No. ED 428036.

Middleton, V.A. (2000) A Community of Learners, Educational Leadership, 57, pp. 51-53.

Nias, J. (1989) Primary Teachers Talking: a study of teaching as work. London: Routledge.

Pennell, J. \& Firestone, W. (1996) Changing Classroom Practices through Teacher Networks: matching program features with teacher characteristics and circumstances, Teachers College Record, 98, pp. 46-76.

Pennell, J. \& Firestone, W. (1998) Teacher-teacher Professional Development through State Sponsored Networks, Phi Delta Kappan, 79, pp. 354-357. 
Richert, A. (1992) Voice and Power, in L. Valli (Ed.) Reflective Teacher Education: cases and critiques. Albany: State University of New York Press.

Sachs, J. (1997) Reclaiming the Agenda of Teacher Professionalism: an Australian experience, Journal of Education for Teaching, 23, 263-275.

Schubert, W.H. \& Ayers, W.C. (Eds.) (1992) Teacher Lore: learning from our own experience. New York: Longman.

Shimahara, N.K. (1998) The Japanese Model of Professional Development: teaching as craft, Teaching and Teacher Education, 14, pp. 451-462.

Vukelich, C. \& Wrenn, L. (1999) What Do We Think We Know? Childhood Education, 75(3), pp. 153-158.

Wilson, S. \& Ball, D.L. (1996) Helping Teachers Meet the Standards: new challenges for teacher educators, Elementary School Journal, 97, pp. 121-138.

Wilson, S.M., Miller, C. \& Yerkes, C. (1993) Deeply Rooted Change: a tale of learning to teach adventurously, in D.K. Cohen, M.W. McLaughlin \& J.E. Talbert (Eds) Teaching for Understanding: challenges for educational policy and practice. San Francisco: Jossey-Bass.

Wigginton, E. (1986) Sometimes a Shining Moment: the Foxfire experience. Garden City: Anchor Press/Doubleday. 
